\title{
Pelatihan E-Learning Google Classroom di SMAIT Asy-Syukriyyah Cipondoh
}

\section{Puji Catur Siswipraptini ${ }^{1}$; Rosida Nur Aziza ${ }^{2}$; Karina Djunaidi ${ }^{3}$; Rahma Farah Ningrum ${ }^{4}$; Abdurrasyid $^{5}$; Riki Ruli Affandi Siregar ${ }^{6}$}

\author{
1,2,3,4,5, ${ }^{6}$ Program Studi Teknik Informatika, Sekolah Tinggi Teknik PLN \\ ${ }^{1}$ pujicatur@sttpln.ac.id
}

\begin{abstract}
SMAIT Asy-Syukriyyah is a high school located in Cipondoh, about $12 \mathrm{~km}$ from STTPLN. This high school has started to implement the distance learning method via the Internet, or known as ELearning, as a complement to the existing teaching and learning process. One of the obstacles faced by the school in organizing E-Learning is the lack of human resources. The ability of teachers and the number of teachers who use E-Learning are still limited, as well as the student's abilities. Therefore, the PKM Team from STT PLN intends to hold training for new students so that these students know the benefits of E-Learning and get to know the basics of using Google Classroom, as an application for E-Learning chosen by the school. The training is divided into several classes, each of which contains approximately 20 students. Each student is given the opportunity to practice directly through a computer or smartphone. The total number of participants who took part in the training was 82 students. And from the questionnaire given, all stated that the training provided was useful.
\end{abstract}

Keywords: E-Learning, Google Classroom, SMAIT Asy-Syukriyah

\begin{abstract}
ABSTRAK
SMAIT Asy-Syukriyyah adalah sekolah menengah atas yang terletak di Cipondoh, sekitar $12 \mathrm{~km}$ dari STTPLN. SMA ini telah mulai menerapkan metode pembelajaran jarak jauh menggunakan Internet, atau E-Learning, sebagai pelengkap dari proses belajar mengajar yang ada. Salah satu kendala yang dihadapi sekolah dalam penyelenggaraan E-Learning ini adalah kurangnya sumber daya manusia. Kemampuan guru dan jumlah guru yang menggunakan E-Learning masih terbatas, begitu pula dari sisi kemampuan siswa. Oleh karena itu, Tim PKM dari STT PLN ini bermaksud mengadakan pelatihan bagi siswa baru supaya siswa-siswa tersebut mengetahui manfaat dari ELearning dan mengenal dasar-dasar penggunaan Google Classroom, sebagai aplikasi E-Learning yang dipilih oleh sekolah. Pelatihan dibagi menjadi beberapa kelas, yang masing-masing berisi kurang lebih 20 siswa. Masing-masing siswa diberi kesempatan untuk melakukan praktik langsung melalui komputer atau telepon pintar. Total peserta yang mengikuti pelatihan adalah 82 siswa. Dan dari angket yang diberikan, semua menyatakan bahwa pelatihan yang diberikan bermanfaat.
\end{abstract}

Kata kunci: E-Learning, Google ClassRoom, SMAIT Asy-Syukriyah 


\section{PENDAHULUAN}

SMAIT Asy-Asyukriyyah adalah salah satu unit pendidikan yang berada di bawah Yayasan Islam Asy-Syukriyyah Tangerang, Provinsi Banten. Yayasan ini didirikan pada tahun 1987 atas gagasan dari beberapa tokoh pendirinya, antara lain: Bapak H.Djaman bin H.Risin dan Bapak H. Acep Abdul Syukur. Berbagai upaya terus dilakukan oleh yayasan ini untuk mencerdaskan masyarakat Tangerang dan sekitarnya melalui kegiatan-kegiatan di bidang pendidikan, da'wah, sosial kemasyarakatan, dan penelitian pengembangan. Adapun visi dari Yayasan Islam Asy-Syukriyah ini adalah sebagai "Pandu Kebanggaan bagi Pemberadaban Lingkungan yang Humanis". Untuk mewujudkan visinya, ada 5(lima) misi yang dimiliki yayasan, yaitu:

1. Membangun strategi pemberdayaan dan pemberadaban lingkungan berbasis pendidikan dan da'wah yang merakyat dan interaktif.

2. Mewujudkan sistem pendidikan yang bermutu, berkesinambungan, humanis, dan berbasis pembentukan pemberadab lingkungan.

3. Memperkuat basis dan daya dukung sosial melalui pelibatan partisipasi lingkungan pada tataran konsep, aktivitas, dan fasilitasi.

4. Mengembangkan pendidikan yang menjadi kebanggaan dan kesadaran puncak pada tataran lokal dan nasional secara permanen.

5. Membangun lingkungandan masyarakat Islami yang menyejukkan, berkemauan kuat, berhasrat maju, dan menjadi rahmatan lil 'alamin dalam ridha Allah SWT [1].

Pada awalnya, Yayasan Islam Asy_Syukriyah (YIAS) mendirikan SMA Islam Asy-Syukriyah dengan sistem pengajaran yang masih konvensional. Namun sejak 2013, YIAS mengubah konsep SMA tersebut menjadi SMAIT (Sekolah Menengah Atas Islam Terpadu) Asy-Syukriyah. Perubahan tersebut diikuti pula dengan pergantian sistem pengajaran dan pembelajaran yang berbasis teknologi dan multimedia [2] . Siswa-siswa sekarang belajar menggunakan laptop dan sekolah menyediakan akses internet supaya siswa dapat mendapatkan informasi yang lebih luas. Pihak SMAIT juga telah berusaha memadukan penggunaan metode pembelajaran E-Learning ke proses belajar mengajar yang ada. Diharapkan dengan adanya E-Learning, proses belajar mengajar tidak lagi dibatasi oleh ruang kelas dan waktu.

E-Learning atau Electronic Learning merupakan hasil penggabungan teknologi informasi dan komunikasi yang memungkinkan sumber-sumber pembelajaran dapat diakses secara online [3]. Definisi lain menyatakan bahwa E-Learning adalah metode pembelajaran yang dimungkinkan karena adanya teknologi digital, atau jaringan internet, atau teknologi berbasis web. Bahkan ada yang menyatakan bahwa E-Learning merupakan seni pembelajaran tanpa menggunakan materi yang tercetak di kertas, melainkan mengandalkan penggunaan teknologi telekomunikasi untuk pengiriman informasi untuk pendidikan dan pelatihan [4]. Ada beberapa keuntungan dan kerugian yang timbul ketika menerapkan E-Learning di sekolah-sekolah. Berikut ini adalah beberapa contoh keuntungan yang diberikan oleh E-Learning:

1. Memberikan kebebasan bagi siswa untuk memilih waktu dan tempat yang sesuai baginya dalam belajar.

2. Memberikan kemudahan bagi siswa untuk mengakses informasi yang lebih banyak.

3. Menyediakan kesempatan interaksi yang lebih besar antar siswa, maupun antara siswa dengan pengajar melalui forum tanya jawab.

4. Memungkinkan siswa belajar dan mengakses materi sesuai dengan kemampuan dan kecepatan belajar masing-masing. 
5. Menawarkan kemudahan dan pengurangan biaya karena siswa tidak harus datang dan berkumpul di suatu ruang khusus untuk belajar.

Adapun beberapa kerugian yang mungkin dihadapi dalam penggunaan E-Learning adalah:

1. Penjelasan materi secara tatap muka langsung dengan pengajar masih dianggap memberikan pemahaman yang lebih baik.

2. Sulit untuk menghindari hal-hal yang negatif, seperti mencontek dan menjiplak karya orang lain.

3. Tidak bisa diterapkan untuk semua bidang ilmu, contohnya ilmu murni yang memerlukan praktik langsung tidak tepat menggunakan sistem ini.

4. Mengurangi kesempatan pengajar untuk meningkatkan kemampuan komunikasi, khususnya dalam penyampaian materi langsung ke siswa [5].

Ada 3 (tiga) model penerapan E-Learning di institusi pendidikan menurut Rashty (1999), yaitu : adjunct, blended learning, dan online [6]. Pada model adjunct, E-Learning digunakan sebagai tambahan dari proses pembelajaran tatap muka yang ada. Pada model kedua, blended atau mixed learning, pembelajaran E-Learning merupakan bagian yang tak terpisahkan dari prosess belajar mengajar. Bentuknya bisa beragam, misalnya pemberian materi di kelas dan pelaksanaan ujian/penilaian secara online via jaringan Internet. Sedangkan pada model fully online, semua proses pembelajaran dari awal sampai tahap penilaian dilakukan secara online. Saat ini, SMAIT AsySyukriyyah sedang berupaya menuju penerapan model blended learning.

Google Classroom adalah salah satu aplikasi yang dapat digunakan untuk mendukung penerapan E-Learning di sekolah-sekolah. Aplikasi yang bebas biaya ini dikembangkan oleh Google bagi sekolah untuk membangun proses belajar mengajar yang bebas kertas dan memudahkan proses pertukaran data/informasi antara pengajar dengan siswa dengan memanfaatkan jaringan Internet. Google Classroom menggabungkan berbagai sumberdaya dari Google, antara lain Google Drive untuk pembuatan dan penyebaran tugas/soal, Google Docs untuk menulis, Gmail untuk komunikasi antara siswa dengan guru, dan Google Calendar untuk keperluan penjadwalan. Banyak penelitian yang dilakukan mengenai penggunaan Google Classroom sebagai salah satu platform pelaksanaan E-Learning di sekolah maupun universitas di berbagai negara. Contohnya adalah penelitian yang dilakukan di Pangasinan State University, Philipina [7], Universiti Utara Malaysia [8], dan riset dari Universitas Pasundan tentang penggunaan Google Classroom untuk pembelajaran Bahasa Indonesia Sekolah Dasar [9] . Secara umum, hasil penelitian tersebut menyatakan bahwa penggunaan Google Classroom untuk menerapkan E-Learning di institusi pendidikan yang diteliti mendapatkan respon yang baik, bahkan dapat meningkatkan minat belajar siswa. Gambar 1 di bawah menunjukkan logo dari Google Classroom.

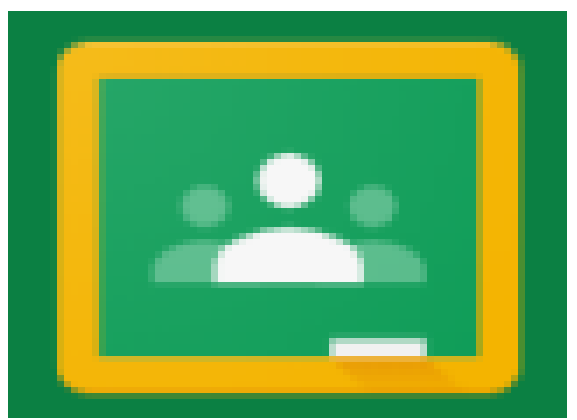

Gambar 1. Logo dari Google Classroom 
SMAIT Asy-Syukriyyah telah memperkenalkan konsep pembelajaran E-Learning melalui penggunaan aplikasi Google Classroom di sekolah. Kendala yang dihadapi oleh pihak sekolah dalam penggunaan Google Classroom adalah keterbatasan sumber daya manusia, baik guru maupun siswa. Masih sedikit guru yang menguasai cara-cara menggunakan dan mengaktifkan Google Classroom. Oleh karena itu, Tim PKM (Program Kemitraan Masyarakat) dari STT PLN, yang terdiri dari dosen dan mahasiswa, bermaksud untuk mengadakan pelatihan mengenai penggunaan Google Classroom di sekolah tersebut.

\section{METODE}

Gambar 2 menunjukkan tahapan pelaksanaan kegiatan Program Kemitraan Masyarakat (PKM) di SMAIT Asy-Syukriyyah, Kecamatan Cipodoh, Kota Tangerang. Pelaksanaan PKM diawali dengan penentuan program dan pemilihan mitra. Beberapa usulan kegiatan PKM dan calon mitra didiskusikan oleh anggota tim. Tahap selanjutnya adalah pembagian tugas dalam tim dan penyusunan proposal kegiatan. Setelah proposal diajukan, tim mulai mengadakan kunjungan ke SMAIT untuk sosialisasi dan pemantapan program. Pelatihan Google Classroom dipilih sebagai kegiatan PKM berdasarkan masalah yang dihadapi oleh mitra. Sebagaimana telah dijelaskan di atas, SMAIT Asy-Syukriyyah sedang berusaha menerapkan E-Learning pada proses belajar mengajar konvensional yang sudah ada. Dan untuk mewujudkan hal tersebut, pihak sekolah memerlukan bantuan untuk mempersiapkan tenaga didik dan sebagian siswa untuk mengaktifkan dan mengoperasikan aplikasi Google Classroom. Koordinasi lanjutan terus dilakukan antara tim PKM dengan pihak mitra terkait dengan waktu pelaksanaan dan calon peserta pelatihan.

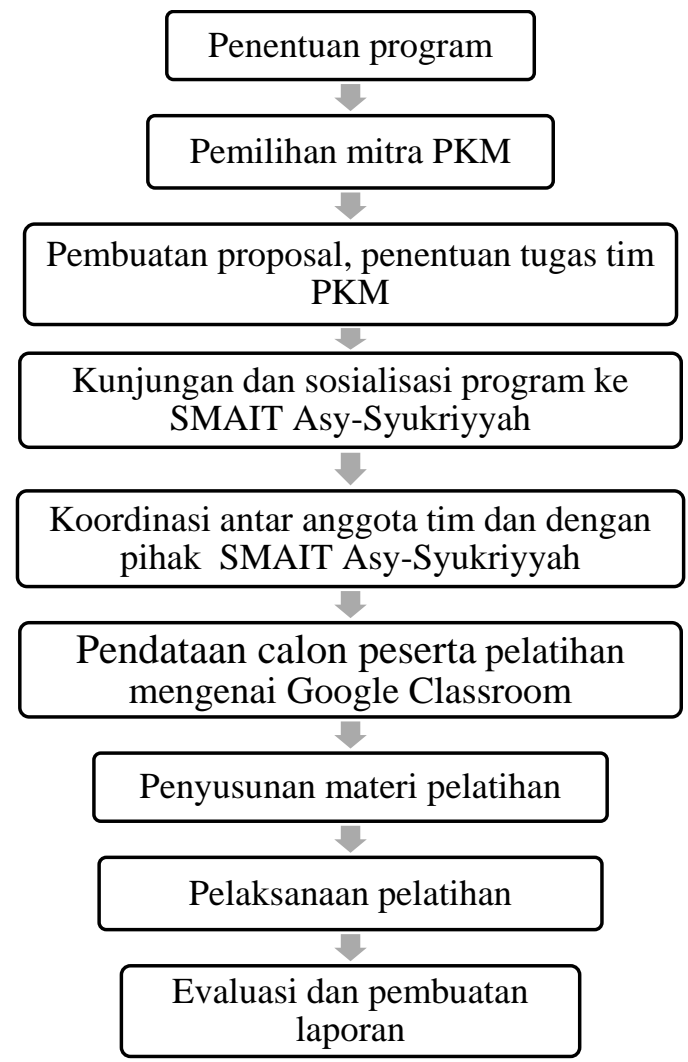

Gambar 2. Tahapan Pelaksanaan PKM 
Pelaksanaan pelatihan E-Learning Google Classroom ini dilaksanakan dalam 2 sesi dengan jumlah peserta adalah 82 orang. Setiap peserta diberi modul pelatihan online dan diberi kesempatan untuk praktik langsung menggunakan komputer atau telepon genggam pintar (smart phone) yang dimiliki peserta atau disediakan sekolah. Adapun langkah-langkah pelaksanaan pelatihan adalah sebagai berikut:

Langkah 1 : Peserta diminta untuk mengisi angket awal.

Langkah 2 : Peserta diberi penjelasan mengenai Google Classroom, berbagai fasilitas dan manfaat yang dapat diperoleh dengan menggunakan aplikasi tersebut.

Langkah 3 : Bagi peserta yang belum memiliki akun di Gmail diminta membuka akun baru supaya bisa terhubung dengan kelas virtual yang akan dibentuk dengan Google Classroom.

Langkah 4 : Peserta diberi kesempatan untuk mencoba mengakses materi-materi pelajaran yang ada di Classroom yang sudah dibuat Pemateri untuk latihan.

Langkah 5 : Peserta dijelaskan mengenai cara mengerjakan dan mengumpulkan tugas secara online, serta mendapatkan nilai dari guru.

Langkah 6 : Belajar melakukan video conference melalui Google Classroom.

Langkah 7 : Pengisian angket akhir kegiatan.

\section{PEMBAHASAN}

Kegiatan PKM dengan judul "Pelatihan E-Learning Google Classroom di SMAIT AsySyukriyyah Cipondoh" diselenggrakan pada tanggal 25 Juli 2019 dan bertempat di ruang kelas X di gedung sekolah SMAIT Asy-Syukriyyah. Pada awalnya, peserta yang akan mengikuti pelatihan adalah guru dan siswa baru. Tim telah menyiapkan materi untuk siswa dan guru. Namun pada hari pelaksanaan, peserta pelatihan hanya terdiri dari siswa kelas $X$ dari Jurusan IPA dan IPS. Total peserta adalah 82 anak. Pelatihan dibagi menjadi 4 kelas dan dalam 2 sesi, yaitu sesi pertama (pukul 10.00-12.00 WIB) dan sesi kedua (pukul 13.00 - 15.00 WIB). Setelah pelatihan, kegiatan ditutup dengan ramah tamah, foto bersama, dan pemberian cindera mata dari tim PKM STT PLN ke pihak sekolah.

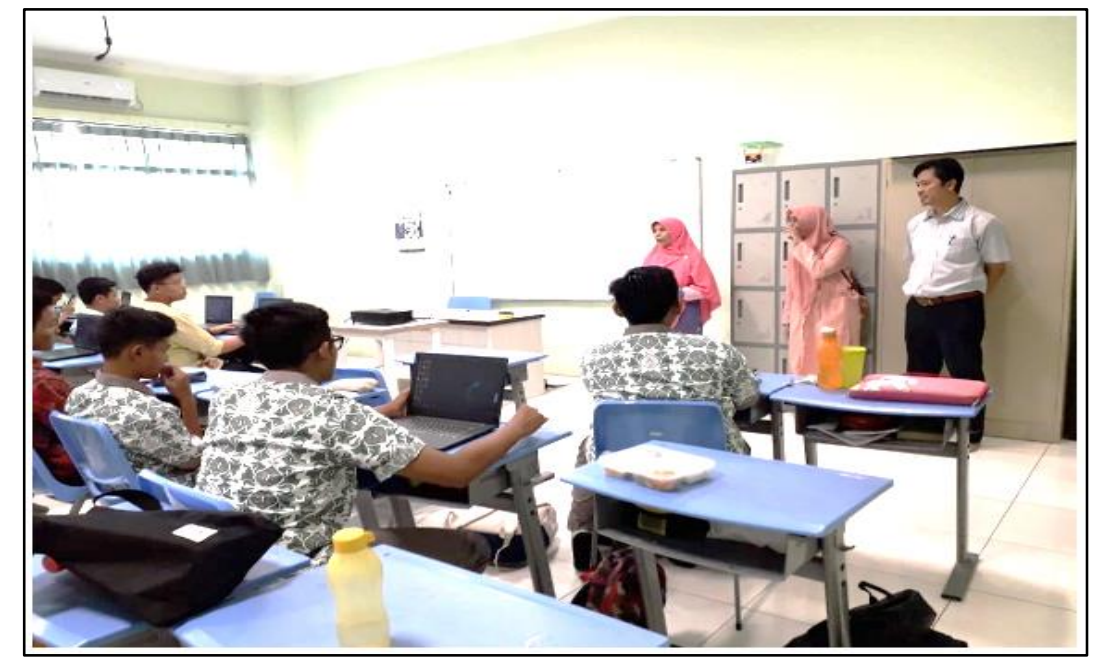

Gambar 3. Pembukaan oleh Kepala Sekolah SMAIT Asy-Syukriyyah 


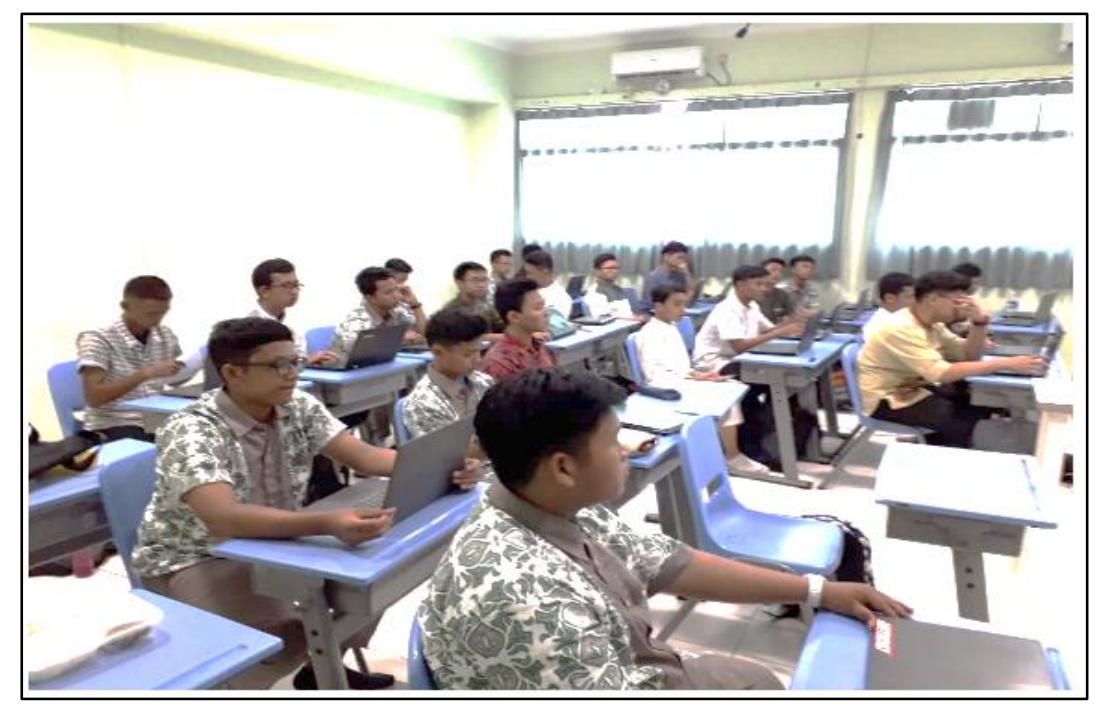

Gambar 4. Suasana Pelatihan Google Classroom

Sebelum pelatihan dimulai, peserta mengisi kuesioner awal terlebih dahulu. Kuesioner tersebut diberikan dengan tujuan untuk mengetahui berapa siswa yang telah memiliki kemampuan dasar dalam pengoperasian komputer dan penggunaan Internet. Dari hasil pengisian questioner tersebut, diketahui bahwa 66 peserta telah memiliki kemampuan dasar komputer, seperti membuat dan menyimpan dokumen serta mengakses Internet. Lima belas (15) siswa menjawab memiliki sebagian dari kemampuan dasar komputer dan hanya satu anak yang menjawab tidak memiliki kemampuan penggunaan komputer dasar. Dari 66 siswa yang telah memiliki kemampuan dasar penggunaan komputer tersebut, sekitar $92 \%$ mampu menggunakan Internet untuk keperluan email, pencarian, mengunggah dan mengunduh dokumen. Grafik pada gambar 5 dan 6 menunjukkan persentase siswa yang telah memiliki kemampuan dasar komputer dan Internet.

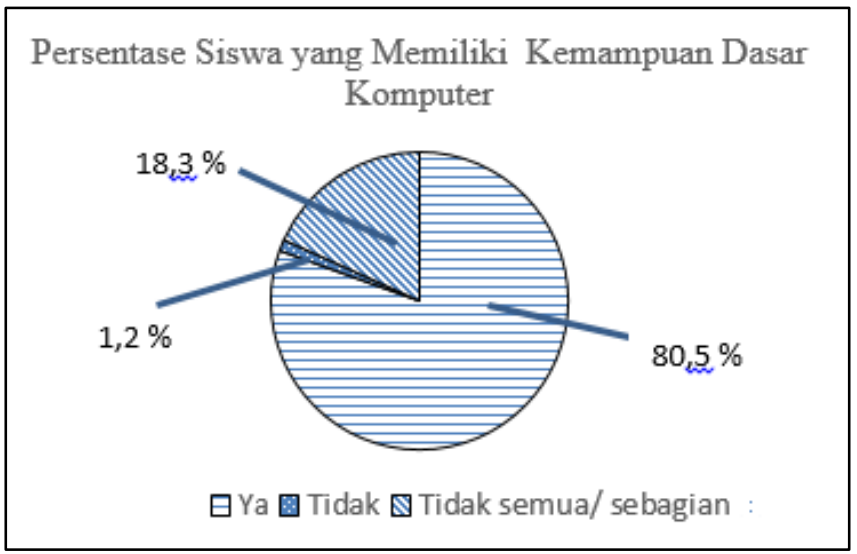

Gambar 5. Grafik Persentase Siswa yang Memiliki Kemampuan Dasar Komputer 


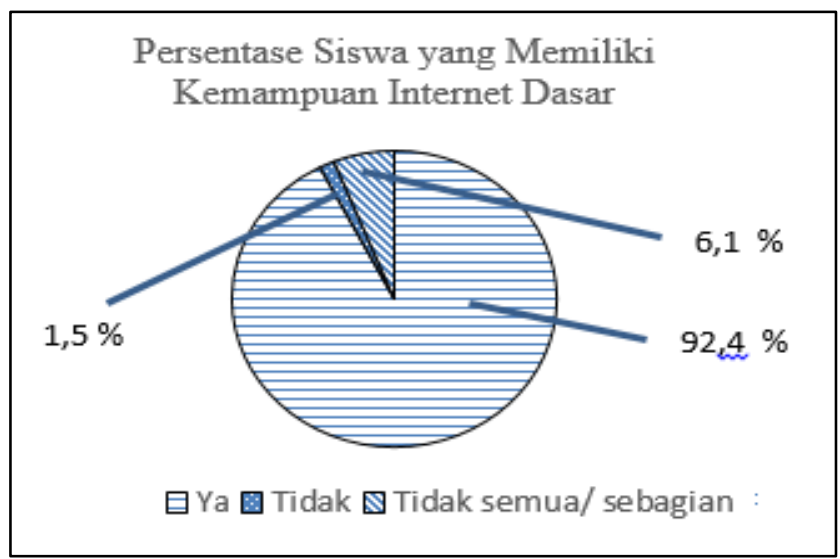

Gambar 6. Grafik Persentase Siswa yang Memiliki Kemampuan Dasar Internet

Dari kuesioner tersebut juga diketahui bahwa siswa beranggapan bahwa SMAIT AsySyukriyyah telah memadukan metode pembelajaran konvensional dengan penggunaan teknologi informasi dan komputer. Walaupun sebagian besar peserta telah memiliki pengetahuan dan ketrampilan dalam menggunakan komputer dan Internet, hanya sebagian kecil yang mengetahui apa yang dimaksud dengan E-Learning. Seperti ditunjukkan pada tabel 1 di bawah ini. Dari 82 peserta pelatihan, semua berminat untuk mempelajari mengenai penggunaan E-Learning untuk menunjang proses belajar mengajar.

Tabel 1. Komposisi Siswa yang Mengetahui tentang E-Learning

\begin{tabular}{|c|c|c|}
\hline $\begin{array}{l}\text { Apakah Anda mengetahui } \\
\text { tentang } \boldsymbol{E} \text {-Learning } ?\end{array}$ & Jumlah Siswa & Persentase \\
\hline Pernah & 22 & $26,8 \%$ \\
\hline Belum Pernah & 44 & $53,7 \%$ \\
\hline Ragu-ragu & 16 & $19,5 \%$ \\
\hline
\end{tabular}

Untuk menunjang pelatihan, seluruh peserta dapat mengakses modul online yang dapat diakses di http://bit.ly/ModulGoogleClassRoomSiswa. Pada awal modul dijelaskan bahwa semua siswa harus memiliki akun Google untuk bergabung dengan Classroom. Selanjutnya peserta dibimbing untuk mulai bergabung dengan kelas yang ada dan mulai mencoba mengerjakan tugas. Berikut ini adalah beberapa langkah awal yang harus dilaksanakan siswa sesuai dengan materi dari dari modul pelatihan:

1. Pastikan Anda memiliki akun Google untuk dapat menggunakan Classroom.

2. Buka aplikasi perambahan website (browser) di komputer PC atau laptop Anda. Masuk ke laman https://classroom.google.com/. Akan muncul tampilan seperti Gambar 7. Klik Lanjutkan. 


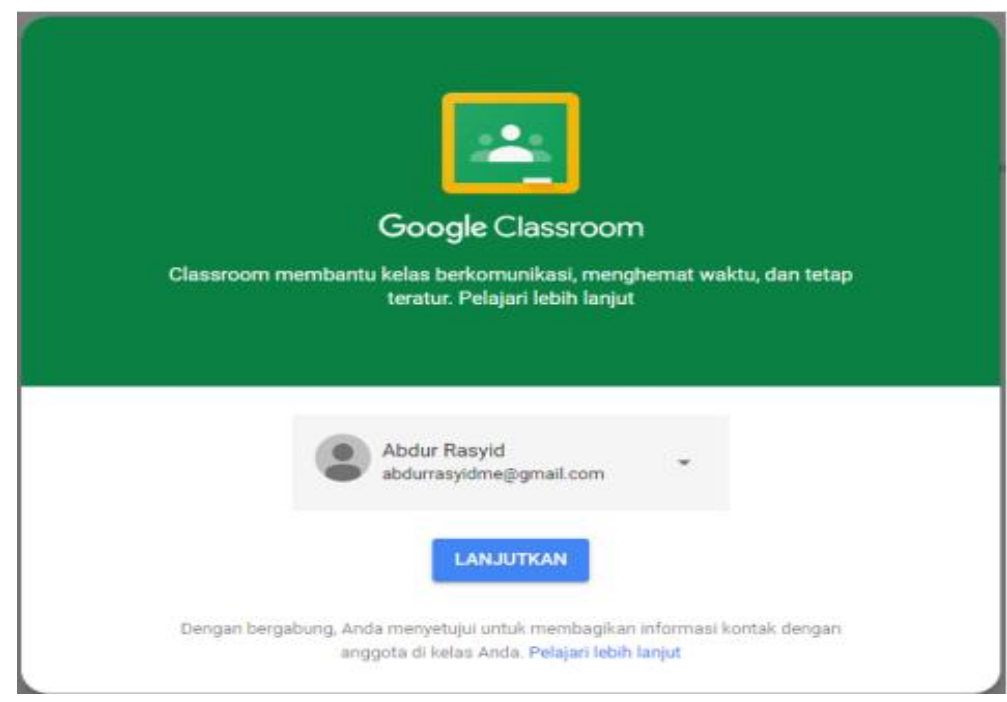

Gambar 7. Tampilan Awal Google Classroom

3. Pada Pojok kanan atas Klik tombol + Pilih "Gabung ke Kelas" untuk masuk ke laman login Akun Google. Untuk gabung dengan kelas yang dipilih, siswa harus memasukkan kode tertentu yang diberikan oleh guru/pengajar, seperti ditunjukkan pada gambar 8 .

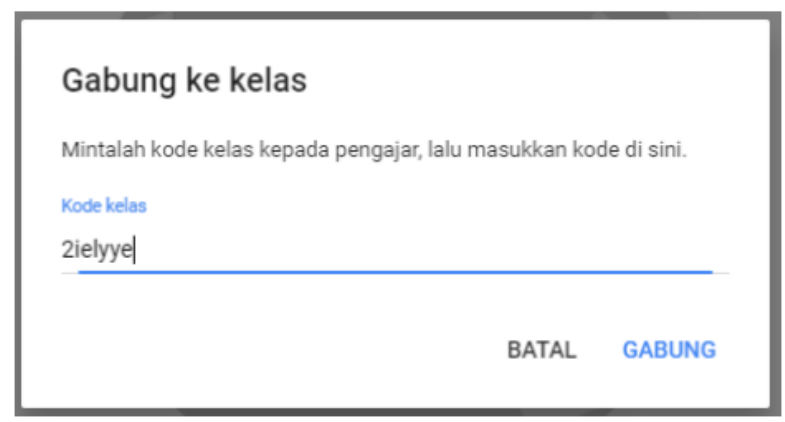

Gambar 8. Form Pengisian Kode Kelas

4. Bila berhasil Anda akan diarahkan pada laman dashboard kelas Anda (gambar 9). Untuk memasukan kode kelas lainnya, klik menu, pilih "kelas", masukan kode kelas sesuai petunjuk yang telah dijelaskan sebelumnya. Lakukan cara yang sama untuk memasukan kode kelas lainnya. 


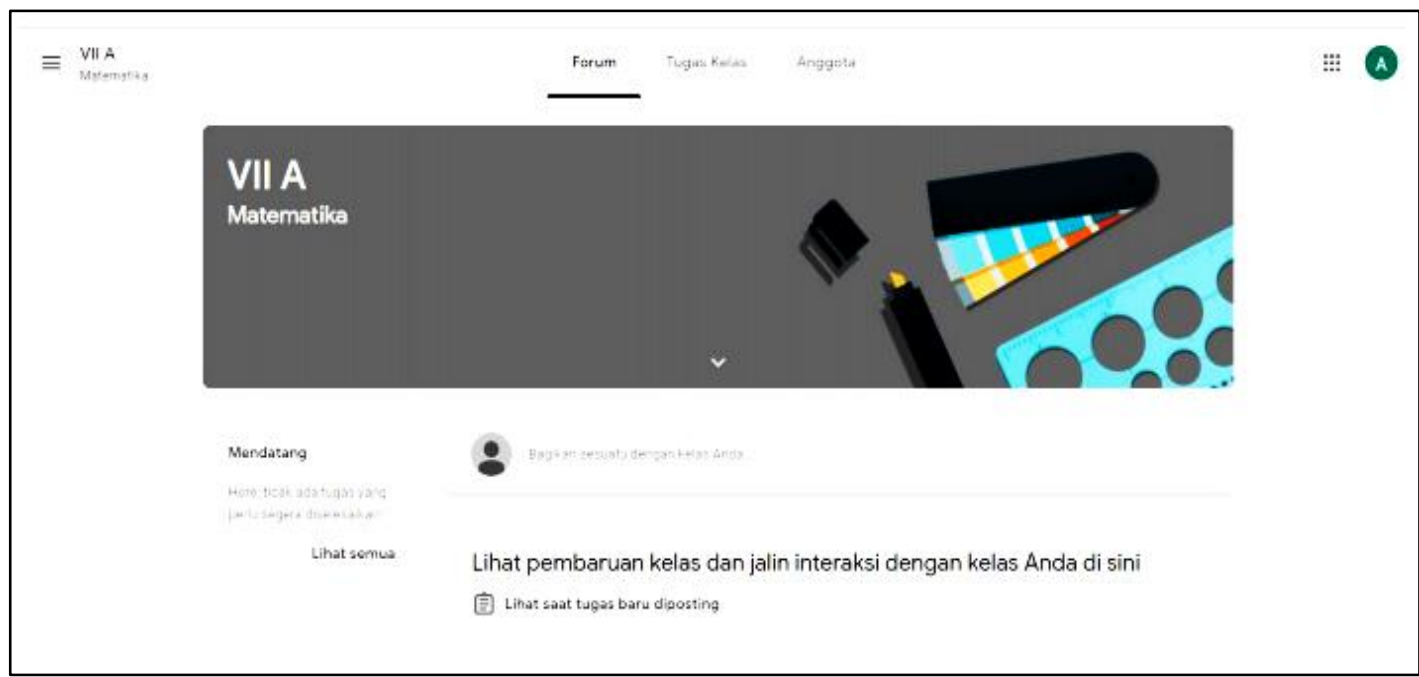

Gambar 9. Contoh Laman Dashboard Kelas yang Dipilih

5. Untuk dapat berinteraksi dengan guru pada kelas yang telah dibuat maka dapat menggunakan fitur Forum.

6. Untuk memulai mengerjakan tugas, klik tombol "buka" pada item judul tugas yang akan dikerjakan, kemudian pilih opsi alat yang tersedia pada Classroom sesuai petunjuk yang tertera pada tugas. Ketika guru memberikan tugas maka akan muncul di tampilan forumForum seperti di bawah ini.

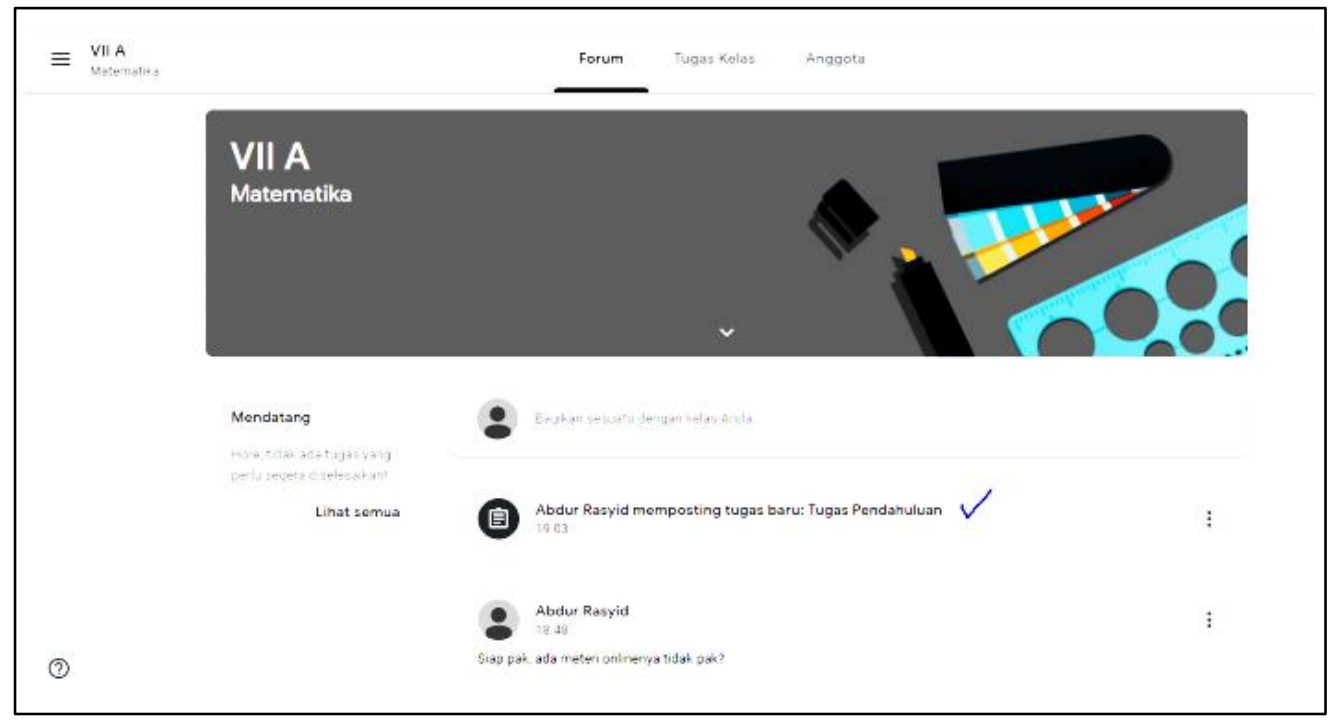

Gambar 10. Tampilan Pemberitahuan Tugas

7. Ketika diklik maka akan tampil pada halaman penyelesaian tugas seperti di gambar 11. Anda dapat menyelesaikan tugas dengan menambahkan dokumen baru. 


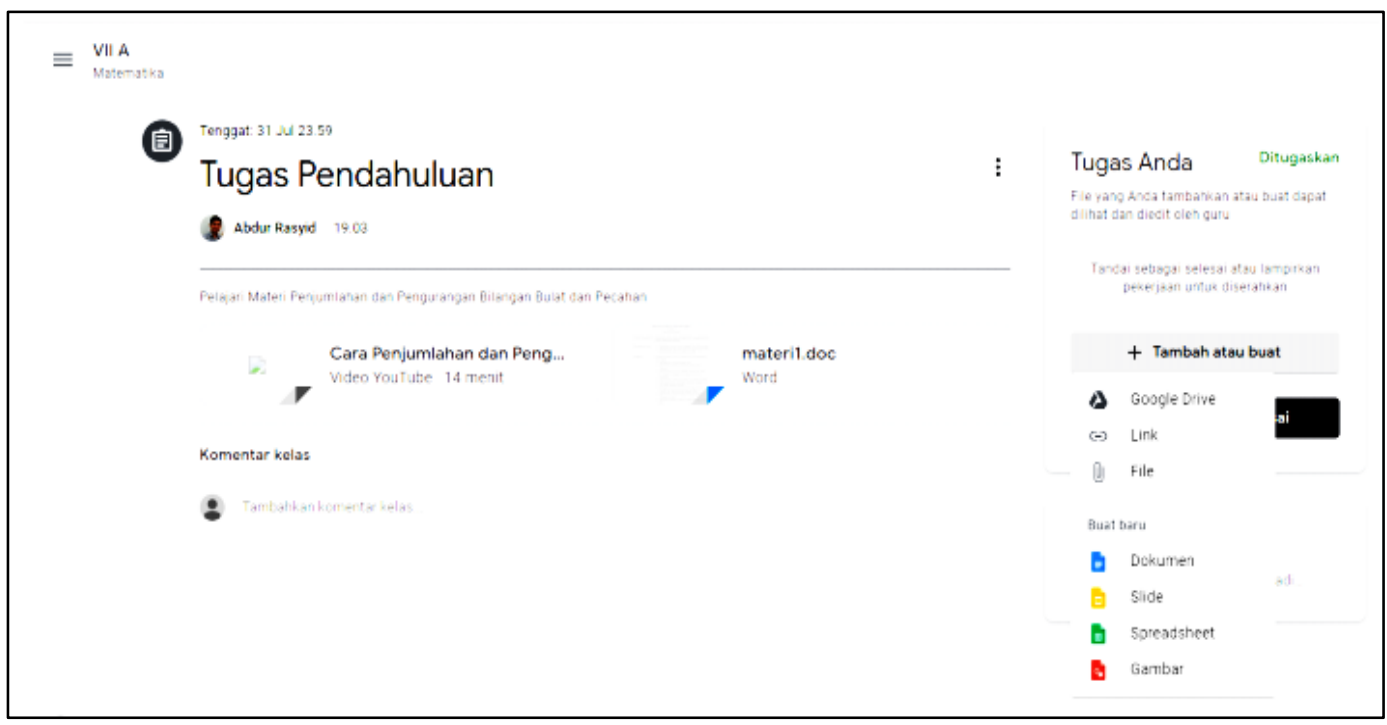

Gambar 11. Tampilan Penambahan Dokumen Baru

Setelah selesai pemberian materi dan praktik, seluruh peserta kembali diminta mengisi kuesioner akhir yang berisi beberapa pertanyaan terkait dengan pelaksanaan kegiatan pelatihan tersebut. Pertanyaan yang diberikan, antara lain apakah materi yang disampaikan mudah dipahami, dan apakah E-Learning Google Classroom dapat mempermudah siswa dalam proses belajar. Kegiatan pelatihan diakhiri dengan sesi foto bersama siswa, guru SMAIT Asy-Syukriyyah dengan anggota tim PKM STT PLN (Gambar 12). Kemudian ditutup dengan pemberian cindera mata kepada pihak sekolah (Gambar 13).

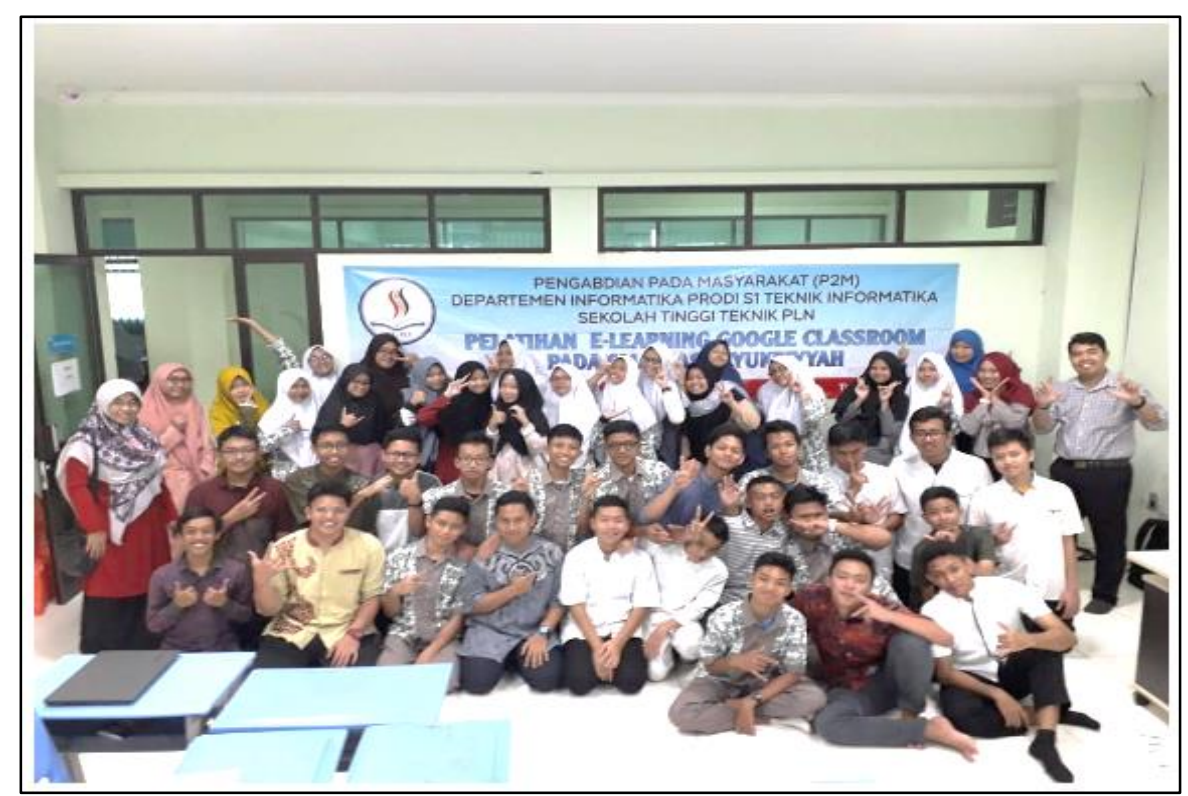

Gambar 12. Peserta Pelatihan Google Classroom dan Tim PKM STT PLN 


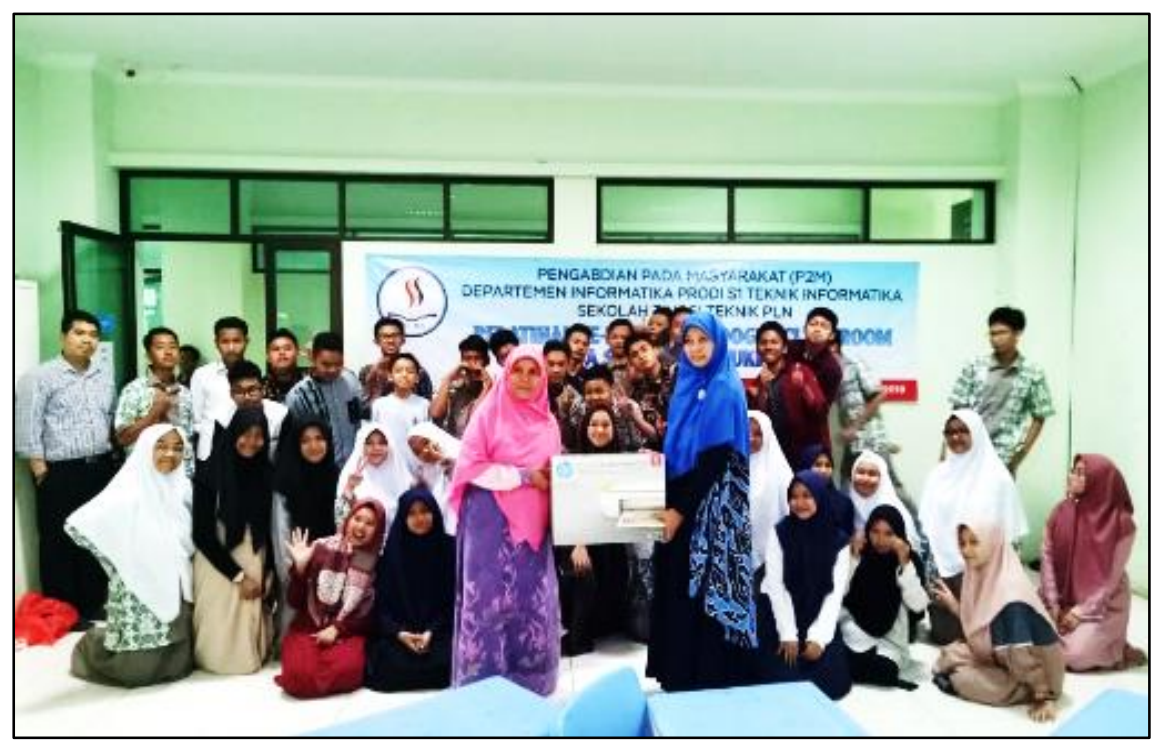

Gambar 13. Penyerahan Cindera Mata dari Ketua Tim PKM kepada Kepala Sekolah SMAIT ASYSyukriyyah, Cipondoh

\section{KESIMPILAN DAN SARAN}

\subsection{Kesimpulan}

Tema kegiatan PKM Semester Genap Tahun Ajaran 2018/2019 di SMAIT Asy-Syukriyah adalah mengenai E-Learning. Sekolah tersebut sedang berusaha menerapkan metode pembelajaran blended learning, yaitu menggabungkan metode pengajaran konvensional tatap muka dengan metode E-Learning. Metode E-Learning, seperti telah dibahas di atas, menawawarkan banyak kelebihan, seperti pengurangan penggunaan kertas, dan kemudahan bagi guru dan siswa untuk bertukar lembar kerja tanpa dibatasi waktu dan tempat. Salah satu kendala yang dihadapi SMAIT Asy-Syukriyyah dalam menerapkan E-Learning dengan aplikasi Google Classroom adalah kurangnya sumber daya manusia yang menguasai materi tersebut, dari guru maupun siswa. Oleh karena itu, tim PKM STT PLN mengadakan pelatihan mengenai penggunaan Google Classroom untuk membantu pihak sekolah. Pada rencana awal, peserta pelatihan adalah beberapa guru yang dipilih sekolah dan siswa. Namun pada pelaksanaannya, peserta pelatihan seluruhnya dari siswa kelas X. Diharapkan, dengan adanya pelatihan mengenai E-learning dan Google Classroom, siswasiswa baru SMAIT tersebut tidak lagi menghadapi kesulitan ketika beberapa guru di kelas menggunakan Google Classroom.

Supaya pelatihan bisa diterima dengan baik, 82 peserta yang terdiri dari siswa kelas X SMAIT Asy-Syukriyyah jurusan IPA dan IPS dibagi dalam 4 kelas. Masing-masing kelas berisi 19, 20, 21, dan 22 anak. Setiap peserta dapat mengakses modul online yang telah disusun tim PKM dan diberi kesempatan praktik langsung dengan komputer atau smartphone masing-masing. Kendala utama yang muncul dalam pelatihan adalah koneksi Internet yang lambat sehingga banyak peserta yang memerlukan waktu cukup lama untuk mengakses Google Classroom. Kendala lain, seperti masalah pengaturan waktu dan pembagian kelompok, dapat ditangani dengan baik karena peran aktif dari pihak sekolah. 


\subsection{Saran}

SMAIT Asy-Syukriyyah adalah sekolah yang sedang giat memadukan penggunaan teknologi informasi dan komputer ke dalam proses belajar mengajarnya dan memberikan kesempatan bagi siswa-siswinya untuk berperan aktif di bidang teknologi. Ada banyak kesempatan bagi Tim PKM dari Departemen Informatika STT PLN untuk menjalin kerjasama dengan sekolah tersebut di semester-semester yang akan datang. Berdasarkan pengamatan dan diskusi dengan pihak sekolah, ada beberapa program yang bisa dilaksanakan di SMAIT Asy-Syukriyyah, yaitu:

1. Pelatihan E-Learning untuk guru.

2. Pelatihan penggunaan perangkat lunak untuk keperluan desain bagi siswa.

3. Pengenalan bahasa pemrograman komputer.

\section{DAFTAR PUSTAKA}

[1] "Yayasan Islam Asy-Syukriyyah Tangerang," 2012. [Online]. Available: http://www.asysyukriyyah.or.id. [Accessed 0808 2019].

[2] S. Ichsan, "Belajar dengan Sistem Pembelajaran Berbasis Teknologi," Republika.co.id, 2801 2017. [Online]. Available: https://republika.co.id. [Accessed 0808 2019].

[3] V. Arkorful and N. Abaidoo, "The Role of E-Learning, the Advantages and the Disadvantages of Its Adoption in Higher Education," International Journal of Education and Research, vol. 2, pp. 397-410, 2014.

[4] S. Goyal, "Future of Education," Journal of Education and Learning, vol. 6, no. 2, pp. 239242, 2012.

[5] P. Deepali, V. Wadhai and V. Thakare, "E-Learning System and Higher Education," International Journal of Computer Science and Mobile Computing, vol. 5, no. 2, pp. 274-280, 2016.

[6] D. Rashty, "E-Learning Models," Rashty Consulting Intuitive Digital Experience, 1999. [Online]. Available: http://www.rashty.com. [Accessed 0808 2019].

[7] K. L. A. Estira, M. J. De Guzman, C. M. Cabaluna and R. J. M. Ventayen, "Usability Evaluation of Google Classroom : Basis for the Adaptation of GSuite E-LearningPlatform," in 6th International Conference on Studies in Business, Management, Education, and Law, Manila, 2017.

[8] I. N. M. Shaharanee, J. M. Jamil and S. S. M. Rodzi, "The Application of Google Classroom as a Tool for Teaching and Learning," Journal of Telecommunication, Electronic, and Computer Engineering, vol. 8, no. 10, pp. 5-8.

[9] F. Inggriyani, A. R. Hamdani and T. Dahlan, "Minat Belajar Mahasiswa dengan Menggunakan Blended Learning melalui Google Classroom pada Pembelajaran Konsep Dasar Bahasa Indonesia SD," Jurnal Ilmu Pendidikan, Keguruan, dan Pembelajaran, vol. 3, no. 1, pp. 28-35, 2019. 